\title{
The Taste of Monosodium Glutamate: Membrane Receptors in Taste Buds
}

\author{
Nirupa Chaudhari, ${ }^{1}$ Hui Yang, ${ }^{1}$ Cynthia Lamp, ${ }^{1}$ Eugene Delay, ${ }^{2}$ Claire Cartford, ${ }^{2}$ Trang Than, ${ }^{2}$ \\ and Stephen Roper ${ }^{3}$

\begin{abstract}
1 Department of Physiology, Colorado State University, Ft. Collins, Colorado 80523, 2Department of Psychology, Regis University, Denver, Colorado 80221, and ${ }^{3}$ The Rocky Mountain Taste and Smell Center, University of Colorado Health Science Center, Denver, Colorado 80262
\end{abstract}

\begin{abstract}
Receptor proteins for photoreception have been studied for several decades. More recently, putative receptors for olfaction have been isolated and characterized. In contrast, no receptors for taste have been identified yet by molecular cloning. This report describes experiments aimed at identifying a receptor responsible for the taste of monosodium glutamate (MSG). Using reverse transcriptase (RT)-PCR, we found that several ionotropic glutamate receptors are present in rat lingual tissues. However, these receptors also could be detected in lingual tissue devoid of taste buds. On the other hand, RT-PCR and $\mathrm{RNase}$ protection assays indicated that a G-protein-coupled metabotropic glutamate receptor, mGluR4, also is expressed in lingual tissues and is limited only to taste buds. In situ hybrid-
\end{abstract}

ization demonstrated that mGluR4 is detectable in $40-70 \%$ of vallate and foliate taste buds but not in surrounding nonsensory epithelium, confirming the localization of this metabotropic receptor to gustatory cells. Expression of mGluR4 in taste buds is higher in preweaning rats compared with adult rats. This may correspond to the known higher sensitivity to the taste of MSG in juvenile rodents. Finally, behavioral studies have indicated that MSG and L-2-amino-4-phosphonobutyrate (L-AP4), a ligand for mGluR4, elicit similar tastes in rats. We conclude that mGluR4 may be a chemosensory receptor responsible, in part, for the taste of MSG.

Key words: umami; gustation; rats; taste buds; chemosensory; glutamate receptors
Taste stimuli commonly are categorized as sweet, salty, sour, and bitter. Glutamate is believed to impart a fifth, unique taste termed "umami" (Kawamura and Kare, 1987). Free glutamate is a natural constituent of many foods, including meats, cheeses, and vegetables, and its taste is potentiated by low concentrations of the ribonucleotides 5'-IMP and 5'-GMP (Sato and Akaike, 1965; Yamamoto et al., 1991). Glutamate also enhances the palatability of foodstuffs and commonly is used as a flavoring in the form of monosodium glutamate (MSG). Despite its ubiquity as a taste stimulus, little is known about how glutamate stimulates taste cells.

Salty, sour, and some bitter tastes are elicited by ions. These stimuli are transduced via permeation through or modulation of ion channels in the apical membrane of taste cells (for review, see Kinnamon, 1988; Roper, 1992; Avenet et al., 1993; Gilbertson, 1993). Transduction mechanisms for other chemical stimuli, such as sugars and amino acids, are believed to involve membranebound receptors on taste cells (for review, see Brand et al., 1991; Lindemann, 1995). In vision and olfaction, receptors that transduce sensory stimuli belong to the large G-protein-coupled superfamily of receptors (Reed, 1992; Lancet and Ben-Arie, 1993; Yarfitz and Hurley, 1994). In taste, electrophysiological (Heck et

Received Feb. 9, 1996; accepted March 25, 1996.

This work was supported by research grants from Kraft General Foods, Umami Manufacturers' Association of Japan, and National Institutes of Health (R01 DC00374 and P01 DC01959) from the National Institute on Deafness and Other Communication Disorders and Biomedical Research Support Grant).

Correspondence should be addressed to Dr. Nirupa Chaudhari, Department of Physiology and Biophysics (R-430), University of Miami School of Medicine, P.O Box 016430, Miami, FL 33101.

Dr. Roper's present address: Department of Physiology and Biophysics (R-430), University of Miami School of Medicine, P.O. Box 016430, Miami, FL 33101 Copyright (c) 1996 Society for Neuroscience $0270-6474 / 96 / 163817-10 \$ 05.00 / 0$ al., 1984; Akabas et al., 1988; Avenet et al., 1988; Cummings et al., 1993) and biochemical (Striem et al., 1989; Hwang et al., 1990; Striem et al., 1991; Ruiz-Avila et al., 1995) evidence suggests that some stimuli, such as saccharin, sucrose, and denatonium (an intensely bitter compound), also may be mediated via G-proteincoupled pathways. Receptors, similar to those in olfactory neurons, have been cloned from lingual epithelia but do not appear to be expressed in taste buds (Abe et al., 1993; Matsuoka et al., 1993). Thus, to date, no membrane receptors for sweet or bitter taste have been identified by molecular cloning.

Also, receptors and intracellular pathways for the transduction of amino acids as taste stimuli are not well defined. It has been postulated that glutamate taste is transduced, in part, by glutamate receptors (GluRs) similar to those found in the brain (Faurion, 1991; Akabas, 1993). Ionotropic glutamate receptors (iGluRs) in the brain include ion channels selectively activated by AMPA, kainate (KA), NMDA; and KA-binding subunits; and the poorly understood $\delta$ and $\chi$ receptors (Hollmann and Heinemann, 1994; Ciabarra et al., 1995). The subunits for these receptors are characterized by four transmembrane helices and are related distantly to ionotropic receptors for other neurotransmitters. In contrast, metabotropic glutamate receptors (mGluRs) contain seven putative transmembrane segments and large, globular $\mathrm{N}$ and C termini (Houamed et al., 1991; Masu et al., 1991; Abe et al., 1992; Tanabe et al., 1992; Nakajima et al., 1993). This family displays no sequence similarity with the extensive superfamily of heptahelical receptors for neurotransmitters, hormones, or odorants. Both classes of glutamate receptors-iGluRs and mGluRsare widely distributed throughout the central nervous system, and a few show scattered expression in some peripheral ganglia.

We show here that several brain GluRs are expressed in the 
Table 1. Ionotropic glutamate receptors detected in vallate and foliate papillae

\begin{tabular}{|c|c|c|c|c|c|}
\hline & AMPA-type & Kainate-type & $\delta$-type & \multicolumn{2}{|c|}{ NMDA-Type } \\
\hline Subtype & & $\mathrm{KA}-2$ & $\delta 1$ & NMDAR1 & NMDAR2d \\
\hline Number of clones obtained & 0 & 2 & 5 & 5 & 4 \\
\hline Insert size & & $482 \mathrm{bp}$ & 452 bp & $467 \mathrm{bp}$ & $476 \mathrm{bp}$ \\
\hline $\begin{array}{l}\text { Identity to published amino } \\
\text { acid sequence }\end{array}$ & & $100 \%$ & $100 \%$ & $100 \%$ & $100 \%$ \\
\hline
\end{tabular}

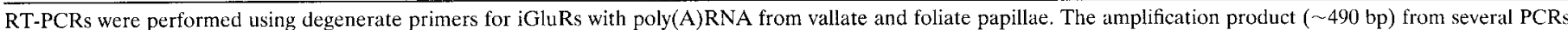

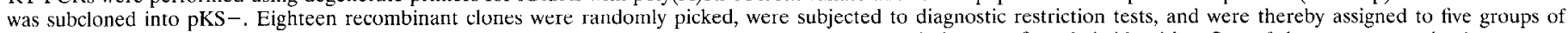

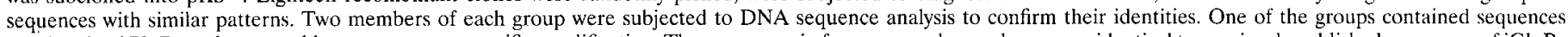

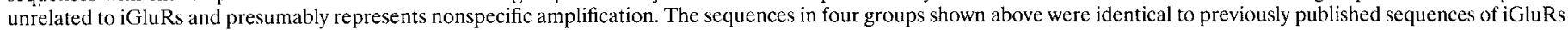
from rat brain.

lingual epithelium but that a single metabotropic receptor, mGluR4, is expressed selectively in taste buds. Based on developmental and behavioral studies, we conclude that mGluR4 may be involved in transducing the taste of glutamate.

Some of these results have been reported previously in preliminary form (Cartford et al., 1994; Chaudhari et al., 1994).

\section{MATERIALS AND METHODS}

Tissues and RNA. Harlan Sprague-Dawley rats were used for all of the reported studies. Experimental tissues were dissected rapidly and frozen on dry ice. Poly(A)RNA was extracted directly by using the Fastrack kil (Invitrogen, San Diego, CA), yielding 0.4-0.8 $\mu \mathrm{g}$ RNA/mg tissuc.

Reverse transcriptase-PCR. Poly(A)RNA $(0.5 \mu \mathrm{g})$ and random hexamer priming were used to generate a single-strand cDNA template for PCR (Saiki et al., 1988). Specific PCR primer pairs were selected with the aid of the Primer Designer 2 program (Scientific and Educational Software). Amplifications were optimized on brain RNAs before proceeding with lingual RNAs and were performed at high annealing temperatures to ensure specificity. To amplify NMDAR1 (Moriyoshi et al., 1991), primers were located in the $\mathrm{N}$-terminal extracellular domain; the primers correspond to the amino acid sequences TMHLLTF (upstream) and PGTKNVTA (downstream).

Degenerate primers were designed to maximize amplification of rare mRNAs (Libert et al., 1989). The degenerate primer pair for iGluRs corresponded to the amino acid sequences $W N(G / R / K) M V G E$ (upstream) and YTANLAA (downstream), located before putative transmembrane in domains I and III, respectively. To assess the efficacy of these primers, we pooled the $\sim 490$ base pair (bp) product from several PCRs from brain RNAs. This complex mixture was digested separately with restriction endonucleases that would generate unique fragments for each of the iGluRs. This assay confirmed the successful amplification of GluR1-7, KA1, KA2, NMDAR1, NMDAR2a-d, $\delta$-1, and $\delta$-2 receptors from brain RNA. [We have not yet tested amplification of $\chi^{-1}$ receptors with our degenerate primers. The sequence has been published only recently (Ciabarra et al., 1995).]

Degenerate primers for mGluRs were localed al amino acid residues (V/I)(N/D)A(V/I)YA(M/I) [5' - tt(ag)a(tc)ge(act)gt(gc)ta(ct)gccat(gt)g$\left.3^{\prime}\right]$ and $\mathrm{L}(\mathrm{V} / \mathrm{L}) \mathrm{TKTN}(\mathrm{R} / \mathrm{C})\left[5^{\prime}-\mathrm{c}(\mathrm{ga})(\mathrm{ga}) \operatorname{tt}(\mathrm{gt}) \mathrm{gtcttggt}(\mathrm{gc}) \mathrm{ag}(\mathrm{gc}) \mathrm{ag}-3^{\prime}\right]$ for the upstream and downstream primers, respectively. I'hese primers span approximately one-third of the extracellular $\mathrm{N}$ terminus and the first three transmembrane hclices. PCRs were optimized using RNA from rat brain plus retina (because mGluR6 is expressed in retina but not appreciably in brain) (Nakajima et al., 1993). PCRs with anncaling temperatures at $55-58^{\circ} \mathrm{C}$ yiclded a hand of the expected size, $\sim 800 \mathrm{bp}$. Replicates of four independent PCRs from brain plus retina were subjected to diagnostic restriction digests. SmaI, NcoI, and $P v u \mathrm{II}$ were used, because recognition sites for these enzymes are present at unique positions in each member of the mGluR family. These diagnostic digests confirmed that mGluR2-6 was unambiguously amplified with our degenerate primers. [After these amplifications were completed, Sauystad et al. (1994) reported the cloning of mGluR7. We do not know whether this receptor is present in taste buds, because the DNA sequence is amplified only inefficiently from brain RNA using our degenerate primers.] Independently, a primer pair specific for mGluR1 [amino acid residues $164--171$ $\left(5^{\prime}\right.$-cagctctgtggccattcaagtc- $\left.3^{\prime}\right)$ and 464-471 (5'-tctcatcgaaccacactcctc$\left.3^{\prime}\right)$ ] readily amplified the expected product from cerebellar RNA but failed to show any amplification product in vallate and foliate papillae.
cDNAs and subclones. PCR products from vallate and foliate papillae, obtained with degenerate primers to iGluRs and mGluRs, were subcloned separately by blunt-end ligation into the SmaI or EcoRV site of bluescript pKS-. Recombinant colonies derived from the iGluR amplifications are described in Table 1. In the case of mGluR amplification from vallate and foliate papillac, all 21 clones analyzed corresponded to mGluR4 by restriction analysis (see Results). One clone in each orientation served as a template for synthesizing RNA probes for in situ hybridizations. A restriction fragment containing the first 332 bp of the mGluR4 PCR product was subcloned into $\mathrm{pKS}$ - for synthesizing antisense probes for RNase protection experiments as shown in Figures 3 and 5.

$R$ Nase protection assay. Single-strand antisense RNAs, labeled with ${ }^{32} \mathrm{P}$ to $\sim 1.5 \times 10^{9} \mathrm{dpm} / \mu \mathrm{g}$, were synthesized using T7 RNA polymerase (Promega, Madison, WI). Approximately $9 \mu \mathrm{g}$ of poly(A)RNA, representing vallate plus foliatc papillac from four to six rats, was uscd for cach hybridization reaction. RNase protection assays were performed essentially as described (Kintner and Melton, 1987) but were modified with a guanidine isothiocyanate step to replace the phenol extractions (Hod, 1992). Protected fragments were analyzed on denaturing $6 \%$ polyacrylamide-urea gels. A template for the positive control, glyceraldehyde 3-phosphate dehydrogenase (GAPDH), was obtained commercially (Ambion, Austin, TX).

In situ hybridization. The method detailed by McLaughlin and Margolskee (1993) for lingual epithelia was used with several modifications, described below, necessary for detecting mRNAs of low abundance. We find that probes synthesized from the $\mathrm{T} 7$ promoter generate less nonspecific background on epithelial sections than those from the T3 promoter. Thus, clones in two orientations were used as templates, allowing us to synthesize both sense and antisense probes using T7 polymerase. Radiolabeled probes were hydrolyzed with alkali; unlabeled herring DNA, used as a blocking agent, was hydrolyzed with acid and alkali (Wisden et al., $1991)$ to improve penetration into cells. Hybridization was conducted at $56^{\circ} \mathrm{C}$ in $0.3 \mathrm{M}$ rather than in $0.6 \mathrm{M} \mathrm{NaCl}$ to raise stringency; an additional high stringency wash $\left(50 \%\right.$ formamide, $2 \times \mathrm{SSC}$ at $60^{\circ} \mathrm{C}$ ) was introduced after RNase digestion. Probes were labeled to $1.5 \times 10^{13} \mathrm{dpm} / \mu \mathrm{g}$ with $\left[{ }^{33} \mathrm{P}\right]$ uridine triphosphate and applied to $10 \mu \mathrm{m}$ tissue sections at $1-3 \times$ $10^{4} \mathrm{dpm} / \mu \mathrm{l}$. Probes for mGluR4, KA2, and NMDARI were validated on frozen sections of rat brain. An intense hybridization signal was obtained only over regions previously shown to express these mRNAs (Moriyoshi et al., 1991; Tandbe et al., 1992; Henley, 1994). The probes did not cross-hybridize to other GluRs in brain sections. Gustducin probes were synthesized from a plasmid provided by Dr. R. Margolskee, Roche Institute.

Conditioned taste aversion. Conditioned taste aversion (CTA) can be induced in rats by injecting $\mathrm{LiCl}$ after the rat has imbibed a neutral taste stimulus. Afterward, the rat will avoid the taste stimulus for many days, presumably because $\mathrm{LiCl}$ produces a temporary visceral distress that is associated with the taste stimulus (Tapper and Halpern, 1968; Smith, 1970; Nowlis et al., 1980).

We conducted two series of CTA experiments for this study. Although MSG has long becn uscd in CTA protocols, effective taste concentrations of AMPA, KA, NMDA, and L-2-amino-4-phosphonobutyrate (L-AP4) have not been measured. Thus, the first series of experiments was conducted to determine whether glutamate agonists could be used in the CTA paradigm and, if so, to establish appropriate concentrations for each agonist. Specifically, we ran a series of experiments aimed at establishing a conditioned aversion to MSG, AMPA, KA, NMDA, or L-AP4. Rats were maintained on a $22.5 \mathrm{hr}$ water deprivation schedule for the duration 
of the experiment. Before conditioning, all animals were entrained to the deprivation schedule and trained to drink in a computer-controlled device that is designed specifically to monitor drinking in rats (Davis MS80 Lickometer, DiLog Instruments, Tallahassee, FL). All conditioning and testing sessions used the lickometer to present water or taste solutions in 32 ten second trials. On the conditioning day, the rats were allowed to ingest either $100 \mathrm{mM}$ MSG ( $n=12$ rats), $5 \mathrm{~mm}$ AMPA ( $n=$ 8 rats), $25 \mathrm{~mm} \mathrm{KA} \mathrm{(} n=12$ rats), $50 \mathrm{~mm} \mathrm{NMDA} \mathrm{(} n=12$ rats), or $10 \mathrm{~mm}$ L-AP4 ( $n=8$ rats) during a $15-20$ min session. Every taste stimulus was presented in 12 or more of the trials, with at least one water trial intervening between each taste stimulus. All solutions of glutamate agonists were titrated to $\mathrm{pH} 6.0-7.0$ to avoid potential complications introduced by acid taste. Also, all solutions, including water, contained $30 \mu \mathrm{M}$ amiloride to minimize the contribution of $\mathrm{Na}^{+}$taste (Heck et al., 1984; Yamamoto et al., 1991; Gilbertson and Gilbertson, 1994). Half of the rats for each taste stimulus were injected intraperitoneally with $0.3 \mathrm{M} \mathrm{LiCl}$ (at $1 \mathrm{ml} / 100 \mathrm{gm}$ body weight). As a control, the remainder were injected with $0.15 \mathrm{M} \mathrm{NaCl}$ (at $1 \mathrm{ml} / 100 \mathrm{gm}$ body weight).

The next day, the rats were given 32 ten second presentations of only water in the lickometer. Two days after conditioning, each rat was presented with several concentrations of the same agonist as had been presented on the day of conditioning. Concentrations spanning two orders of magnitude were presented randomly to establish the thresholds and gradients for aversion to each agonist. For each rat, lick rates for each taste stimulus were divided by the mean lick rate for the intervening water trials. Concentrations of each agonist for which this ratio [lick ratio (LR)] fell between 0.7 and 0.8 were assumed to be near the threshold at which rats avoided consuming the solution and were defined as the "low" concentration in the second CTA experiment (below). A "medium" concentration for each agonist was selected from concentrations that yielded LR values of $0.35-0.7$, i.e., in which avoidance was approximately half maximum. A third, "high," concentration was selected that yielded LR values below 0.35 . The gradients became nonlinear at more elevated concentrations. The low, medium, and high concentrations for each substance contained (in mM): MSG 1.5, 15, and 50; AMPA 0.1, 1, and 5; KA 0.5, 5, and 25; NMDA 0.5, 10, and 25; L-AP4 0.1, 5, and 10 .

The second series of experiments tested whether rats conditioned to avoid MSG generalized this aversion to any of the glutamate agonists (see Fig. 6). Water-deprived rats $(n=64)$ were presented with $100 \mathrm{~mm} \mathrm{MSG}$ in a $15-20 \mathrm{~min}$ session, as above. Immediately afterward, half the rats were injected with $\mathrm{LiCl}$ (experimentals) and half with $\mathrm{NaCl}$ (controls). Two days later, each rat was tested with water, $150 \mathrm{~mm} \mathrm{MSG}, 25 \mathrm{~mm} \mathrm{KCl}$, $100 \mathrm{~mm}$ sucrose, and three concentrations (low, medium, and high) of a glutamate agonist, all presented in random order. Thus, each of the test solutions shown in Figure 6 was presented to two groups of rats, an experimental group and a control group. Each taste stimulus was presented for $10 \mathrm{sec}$ twice during the 32 trial test session. Presentations of taste stimuli were alternated with presentations of water. As before, all solutions were held at $\mathrm{pH} 6-7$ and contained $30 \mu \mathrm{M}$ amiloride. For each rat and for each presentation, the lick rate for a taste stimulus was divided by the mean lick rate for the intervening water trials, as in experiment 1 . These LRs were used to conduct the statistical analyses included in the Results. In Figure 6, to simplify the display of data and to show comparisons between MSG and glutamate agonists, normalized LRs are plotted. That is, the LR for each concentration of stimulus for each experimental rat (injected with $\mathrm{LiCl}$ ) was normalized to the averaged value of LR for the same concentration of stimulus for the group of control rats (injected with $\mathrm{NaCl}$ ). These normalized ratios (mean $\pm \mathrm{SEM}$ ) are plotted on the ordinate in Figure 6.

$\mathrm{KCl}$ was included in these tests as a neutral distractor. Preliminary CTA studies (data not shown) indicated that the rats readily detected 25 $\mathrm{mM} \mathrm{KCl}$ but that this concentration was not inherently aversive. Therefore, we used $\mathrm{KCl}$ to test for a "dirty water effect" (Spector and Grill, 1988), by which rats might avoid all unfamiliar taste substances in a nonspecific manner. The shaded band across the top of Figure 6 indicates the range of responses obtained for $25 \mathrm{mM} \mathrm{KCl}$ in these experiments. These data establish the range of nonspecific aversion which might have occurred in this experiment. Only responses falling outside this range should be considered specific aversions to taste stimuli.

We also tested rats with $100 \mathrm{~mm}$ sucrose, because MSG aversion is known to generalize to sucrose in the presence of amiloride (Yamamoto et al., 1991). This control was included to validate the conditioning paradigm in the event that none of the agonists had shown any generalization. We found that aversion to MSG did generalize to sucrose for all groups of animals (normalized LR $=0.28 \pm 0.02 ; n=32$ ). Beyond its

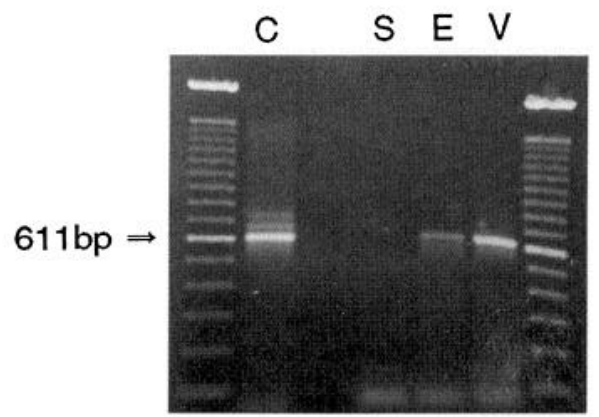

Figure 1. RT-PCR to detect NMDA-glutamate receptor expression in lingual epithelium. Poly(A)RNAs from several tissues were reversetranscribed and subjected to PCR using primers specific for NMDAR1. Tissues analyzed included cerebellum $(C)$, which expresses NMDARs; skeletal muscle $(S)$, which is not known to express any GluRs; lingual epithelium $(E)$, which lacks taste buds; and vallate plus foliate papillae $(V)$, which contain abundant taste buds. The gel was loaded with $5 \mu \mathrm{l}$ of each reaction. With cerebellar RNA, the expected $611 \mathrm{bp} \mathrm{PCR} \mathrm{product}$ (arrow) was consistently obtained, as well as faint higher bands that correspond to alternative splicing variants within the amplified region (Durand et al., 1992; Nakanishi et al., 1992). The far left and right lanes contain a 100 bp ladder.

function as an assay of MSG generalization, our data do not provide additional insights as to the interactions between MSG and sucrose.

\section{RESULTS \\ iGluRs}

In mammals, clusters of chemosensitive cells are the primary receptors for the sense of taste. Vallate and foliate papillae on the surface of the tongue contain taste buds that are known to be stimulated by glutamate. Brand et al. (1991) reported that glutamate activates $\mathrm{Ca}^{2+}$-permeable channels in reconstituted membranes derived from lingual epithelium. Therefore, we initially applied a reverse transcriptase (RT)-PCR strategy to search for iGluRs selective for NMDA. In one series of experiments, PCR primers specific for NMDAR1 (a ubiquitous subunit of NMDARs) (Moriyoshi et al., 1991) were used. In amplifications with poly(A)RNA from vallate and foliate taste papillae, the expected $611 \mathrm{bp}$ product was detected and was confirmed to be NMDAR1 by subcloning and sequencing. The results indicate the presence of NMDAR1 in tissues containing taste buds (Fig. 1). However, a similar PCR product also was obtained from RNA from surrounding nontaste lingual epithelium. Thus, although NMDARs clearly are present in lingual tissue, they seem not to be associated specifically with taste buds.

We also used primers for the GluR1-4 subfamily of (AMPAselective) iGluRs. Using poly(A)RNAs from rat tissues, we did not obtain PCR products from vallate and foliate papillae nor from lingual epithelium devoid of taste buds (data not shown). To determine whether additional iGluRs also might be expressed in lingual epithelia, we used degenerate PCR primers for the entire superfamily of iGluR sequences. Amplifications using brain RNA yielded an intense band at the expected size of $\sim 470 \mathrm{bp}$, which was verified by restriction digestion, to contain all members of the iGluR superfamily. These validated degenerate primers were used in PCRs with mRNA from rat vallate and foliate papillae and consistently yielded a product of the expected size ( $\sim 470 \mathrm{bp}$ ). PCR products from multiple reactions using separate batches of vallate and foliate RNAs were pooled and subcloned into a plasmid vector. Restriction digests were used as diagnostics to assign recombinants to receptor subtypes, as indicated in Table 1. 


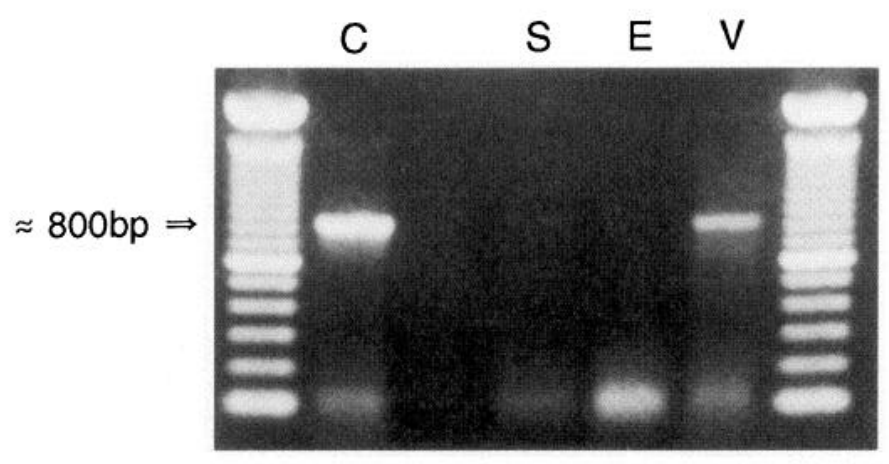

Figure 2. RT-PCR to identify mGluR expression in lingual epithelium. Poly(A)RNAs from several tissues were reverse-transcribed and subjected to PCR using degenerate primers for the family of mGluRs. Tissues analyzed included cerebellum $(C)$, which expresses mGluRs; skeletal muscle $(S)$, which is not known to express mGluRs; lingual epithelium $(E)$, which lacks taste buds; and vallate plus foliate papillae $(V)$, which contain abundant taste buds. The gel was loaded with $5 \mu \mathrm{l}$ from the cerebellum reaction and $50 \mu \mathrm{l}$ (concentrated by ethanol precipitation) of the other reactions. The arrow indicates the expected amplification product at $\sim 800$ bp. The far left and right lanes contain a 100 bp ladder.

Then two members of each category were subjected to DNA sequence analysis to confirm the assignment and showed $100 \%$ identity to the published sequences of synaptic iGluRs. The results show that certain iGluRs-specifically, NMDAR1, NMDAR2d, KA2, and $\delta$-1-are present in lingual tissues. Not all members of every subfamily were found in this analysis. However, we found that the same iGluR sequences also were amplified when lingual epithelium lacking taste buds was used as a source of RNA. Thus, it seems that NMDARs, as well as other iGluRs, are not restricted to taste buds.

Although the PCR results implied that iGluRs are found in taste and nontaste epithelia alike, we also performed in situ hybridizations for KA2 and NMDAR1 to test this conclusion. ${ }^{33}$ P-labeled sense and antisense RNA probes were hybridized on adjacent sections as described in Materials and Methods. Unevenly distributed silver grains were visible over lingual sections, i.e., over taste buds and nonsensory and glandular epithelia. We could detect no consistent localization over any specific cell type. Thus, the PCR products obtained for iGluRs may represent mRNA concentrations below the limit of detection by in situ hybridization. The presence of mRNA for NMDAR1 has been reported in enteric neurons and autonomic and sensory ganglia (Shigemoto et al., 1992; Burns et al., 1994; Watanabe et al., 1994). We did not observe any ganglia or neurons showing positive hybridization for NMDAR1, KA2, or mGluR4 in our lingual sections.

\section{mGluRs}

We also used RT-PCR to test for the presence of mRNAs for mGluRs in rat taste buds. Degenerate primers specific for the family of mGluRs were selected from regions of high sequence identity. (The amplified segment included 185 amino acid residues of the extracellular $\mathrm{N}$ terminus and the first three transmembrane helices.) These primers readily amplified mGluRs from brain RNA, as determined by restriction digests of PCR products (see Materials and Methods). RNA from taste bud-enriched lingual tissue (vallate and foliate papillae) yielded an amplification product of the expected size, $\sim 800$ bp (Fig. 2). RNA from lingual epithelium lacking taste buds did not yield this amplification product, implying that in lingual epithelium only taste buds ex- press mGluRs. Parallel amplifications using iGluR and mGluR degenerate primers on the same batches of mRNA from taste and nontaste epithelia confirmed that only mGluRs seemed to be limited to taste buds.

Restriction analyses of products from 10 RT-PCRs from taste papillae consistently and unequivocally demonstrated that all of the amplified DNA represented mGluR4. Products from several RT-PCRs of taste papillae were subcloned. All clones that were subjected to restriction analysis $(n=21)$ displayed identical digestion patterns. The DNA sequences of two representative clones were determined and were found to be $100 \%$ identical to the corresponding region of mGluR 4 from rat brain (Tanabe et al., 1992). We found no evidence for mGluR1, 2, 3, 5, or 6 in taste papillae. Thus, although the degenerate primers we used allowed the amplification of mGluR1-6, the product from lingual papillae seemed to represent only a single species, mGluR4.

RNase protection assays, although less sensitive than RT-PCR, provide an independent, reliable, and quantitative estimate of mRNA expression in tissues. A radiolabeled RNA probe was synthesized from the subcloned PCR product (i.e., mGluR4) from vallate papillae. After hybridization with poly(A)RNA from cerebellum (positive control tissue) and vallate and foliate papillae, similar protected fragments of the expected size were obtained (Fig. 3). Very faint or no bands were visible in the corresponding region of the gel when RNA from epithelium devoid of taste buds was hybridized to the mGluR4 probe. (These faint bands were not statistically distinguishable from nonspecific background bands when the gels were analyzed densitometrically.)

\section{Localization of mGluR4}

Because RT-PCR and RNase protection suggested mGluR4 expression only in lingual tissues that contain taste buds, we used in situ hybridization to resolve mGluR4 expression at the cellular level. Probes were single-strand RNAs, labeled with ${ }^{33} \mathrm{P}$ and applied to sections of lingual epithelium. Epithelium from vallate and foliate papillae was compared to adjoining epithelium devoid of taste buds. Hybridization with an mGluR4 antisense probe yielded clusters of silver grains over $40-70 \%$ of taste buds in foliate and vallate papillae (Fig. $4 A, B, D$ ). No signal was detected above background on surface epithelium or over regions lacking taste buds. Furthermore, mGluR4 RNA was absent from glands, connective tissue, and muscle within the same tissue sections. Parallel hybridization with a sense (control) probe showed no signal above background (Fig. $4 C, E$ ). Although we have not performed quantitative measurements, grain densities over foliate taste buds seemed consistently higher than those over vallate taste buds.

Also, in situ hybridizations were conducted in parallel with antisense probes either for mGluR4 or gustducin, a taste-specific G-protein (McLaughlin et al., 1992). Grain densities after autoradiography suggested that mRNA levels for mGluR4 were 30100 times lower than for gustducin (compare Fig. 4, $D$ and $F$ ). Although we have no explanation for this phenomenon, a similar imbalance has been noted earlier in olfactory receptor neurons. Using quantitative PCR, Margalit and Lancet (1993) demonstrated that mRNA for the olfactory-specific $G$-protein $G_{\text {olf }}$ is over 100 -fold more abundant than mRNAs for odorant receptors.

The low concentration of mGluR4 mRNA may place it near the limit of detection by in situ hybridization and may account for the lack of signal over some taste buds. Furthermore, the resolution of our in situ hybridizations does not permit us to determine how many cells within a taste bud express mGluR4 mRNA. 


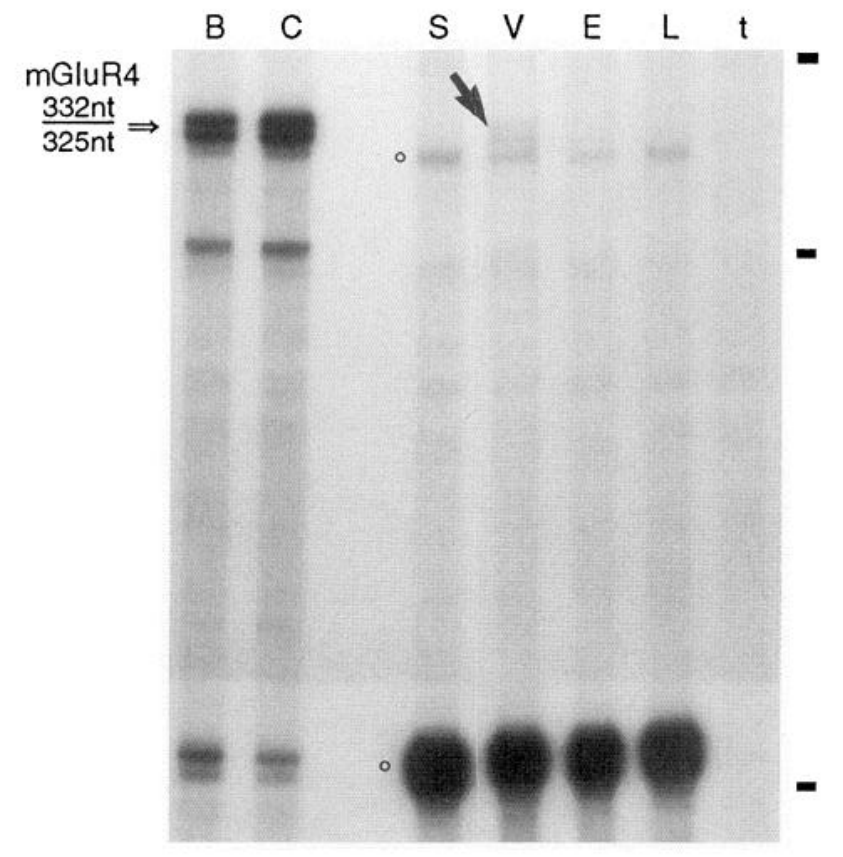

Figure 3. RNase protection assay to assess the relative concentration of mGluR4 mRNA in taste buds and in surrounding epithelium. Singlestrand $\left[{ }^{32} \mathrm{P}\right] \mathrm{RNA}$ antisense probe was synthesized for mGluR4, hybridized in solution, and protected from RNase digestion by $0.2 \mu \mathrm{g}$ poly(A)RNA from positive control tissues, brain $(B)$ and cerebellum $(C)$. The expected band of a protected probe (a doublet at 332/325 nt) is indicated by an arrow. Hybridization with $9 \mu \mathrm{g}$ of poly(A)RNA from vallate plus foliate papillae $(V)$ also shows the same doublet band $(x)$. Hybridization with 9 $\mu \mathrm{g}$ of poly(A)RNA from lingual epithelium that lacked taste buds $(E)$ showed no mGluR4 bands, nor were protected fragments visible in parallel reactions containing $9 \mu \mathrm{g}$ each of tRNA $(t)$ or poly(A)RNA from liver $(L)$ or skeletal muscle $(S)$. The hybridization reactions also contained a [ $\left.{ }^{32} \mathrm{P}\right]$ RNA probe for GAPDH, a ubiquitous glycolytic enzyme, which gives rise to two protected bands, the principal one at $151 \mathrm{nt}$ and a secondary band at $315 \mathrm{nt}(\mathrm{O})$. GAPDH band intensities indicate approximately equal loading in the negative control and test RNAs. The positive controls were underloaded to avoid overexposing the film. Autoradiographic exposure, $15 \mathrm{~d}$. Hatch marks on the right indicate bands from a single-strand RNA marker (415, 276, and $145 \mathrm{nt})$.

\section{Is mGluR4 a chemosensory receptor?}

The preceding results demonstrate that, in lingual tissue, mGluR4 is localized selectively to taste buds. We asked whether this receptor might serve as a primary receptor for MSG as a taste stimulus. Juvenile rodents, before weaning, have a higher taste sensitivity for MSG than do adults (Ninomiya et al., 1991). Thus, we asked whether the expression levels of mGluR4 in taste buds of young versus adult rats were correlated with the known differences in taste sensitivity. As shown in Figure $5 A$, RNase protection indicated that the concentration of mGluR4 mRNA is higher in preweaning rats (3-4 weeks old) than in adult rats (3-4 months old). Densitometric analyses of three such experiments indicated that mGluR4 mRNA is present at two- to threefold higher levels in young versus adult rats. Similarly, parallel in situ hybridizations demonstrated that vallate taste buds from 19- to 25-d-old juvenile rats contained higher concentrations of mGluR4 mRNA (as evidenced by grain density) than those from adult rats (Fig. $5 B, C$ ). These data suggest a correlation between glutamate taste sensitivity and mGluR4 expression in young versus adult rats. Such a correlation supports the postulate that mGluR4 is a taste receptor.
To test the hypothesis that mGluR4 is a chemosensory receptor for MSG, we applied a behavioral assay, CTA. This method determines whether a given stimulus (in this case, MSG) resembles, i.e., generalizes to the taste of another substance (Tapper and Halpern, 1968; Smith, 1970; Nowlis et al., 1980; Spector and Grill, 1988). If mGluR4 is a primary taste receptor, then its activation by either glutamate or an appropriate pharmacological agonist should elicit similar taste perceptions. CTA should reveal such a similarity.

In our CTA experiments, rats were allowed to imbibe $100 \mathrm{~mm}$ MSG, which they readily consumed. Then they were injected intraperitoneally with $\mathrm{LiCl}$ to induce temporary gastric distress; control rats were injected with $\mathrm{NaCl}$, which had no effect. Rats conditioned to avoid MSG were presented with solutions of AMPA, KA, NMDA, and L-AP4. These are known agonists for subsets of iGluRs and mGluRs. Conditioned rats exhibited a strong dose-dependent aversion to MSG itself (Fig. 6, filled circles), confirming that the CTA learning paradigm was successful. MSG-conditioned rats displayed no aversion to solutions of AMPA or NMDA, implying that these agonists do not activate the taste receptor for glutamate. Rats conditioned to avoid MSG showed only a slight aversion to KA at the highest concentration. In contrast, MSG-conditioned rats (but not naive, unconditioned rats) exhibited a strong, dose-dependent aversion to L-AP4 (Fig. 6, open squares). These experiments indicate that, to rats, the perceived taste of L-AP4 is similar to that of MSG. L-AP4 is a known agonist for mGluR4 and mGluR6, of which only mGluR4 seems to be expressed at significant concentrations in taste buds. Thus, the CTA data suggest that activation of mGluR4 by L-AP4 mimics the natural activation of a taste receptor by MSG. The absence of aversion against NMDA and AMPA and only weak aversion against KA demonstrate that activation of iGluRs does not mimic the taste of MSG and highlights the specificity of the behavioral response to L-AP4.

\section{Statistical analyses of CTA experiments}

We performed a number of statistical analyses to test the validity of our conclusions from the CTA experiments. Unconditioned, water-deprived rats imbibed all taste stimuli, including glutamate agonists. Mean lick rates for each taste stimulus ranged from 51 to 62 licks $/ 10 \mathrm{sec}$. To compare responses to taste stimuli from animal to animal and across experimental groups, we calculated an LR for each taste stimulus for each rat (see Materials and Methods). LR values from each experimental group (rats injected with $\mathrm{LiCl}$ ) and control group (rats injected with $\mathrm{NaCl}$ ) were compared, and $F$ ratios were calculated using ANOVA procedures and, as appropriate, simple effects or Newman-Keuls tests.

Two series of experiments were conducted, as explained in Materials and Methods. In the first series, we determined optimum concentrations of glutamate agonists to use in the second series. In the first series of experiments, rats from control groups (those injected with $\mathrm{NaCl}$ ) exhibited $\mathrm{LR}$ values between 0.9 and 1.1 for all taste stimuli during their testing sessions (all $F$ ratios $<2.0$ ). In contrast, for experimental rats (those injected with $\mathrm{LiCl}$ ), the mean LRs for $150 \mathrm{~mm}$ MSG and for the highest concentration of each glutamate agonist were $<0.35$. All ANOVAs found significant differences between the respective control and experimental groups (all $p<0.01$ ). These data showed that rats could be conditioned to avoid the glutamate agonists used in this study. The data also established concentrations of agonists that were appropriate to test in the second series.

In the second series, we conditioned an aversion to MSG and 

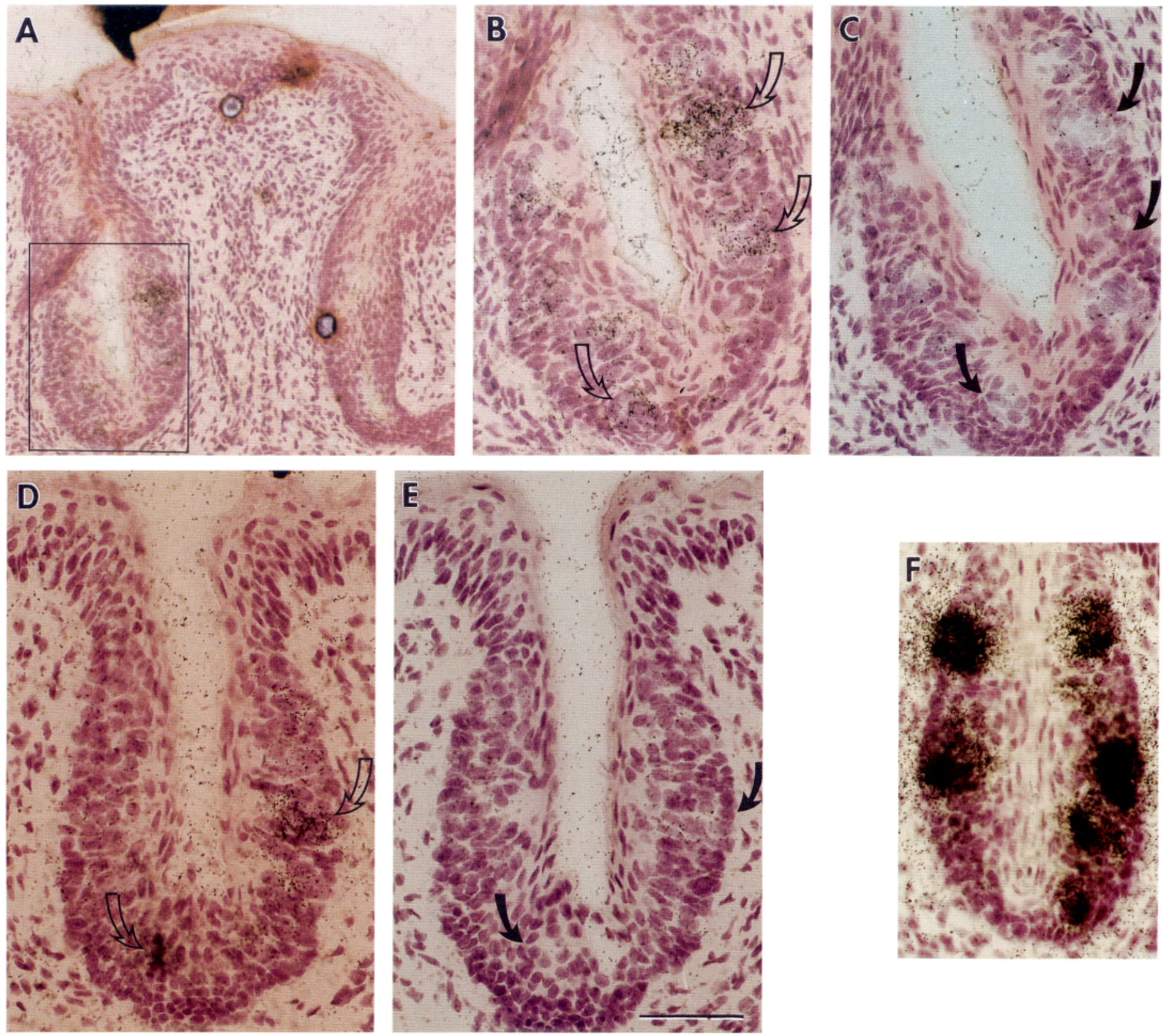

Figure 4. In situ hybridization for mGluR4 in rat vallate and foliate papillae. $\left[{ }^{33} \mathrm{P}\right] \mathrm{RNA}$ probes for mGluR4 were synthesized using T7 RNA polymerase. Adjacent sections of vallate $(A-C)$ and foliate $(D-F)$ papillae were hybridized in parallel with probes in antisense $(A, B, D)$ or sense $(C, E)$ orientation. The boxed area in $A$ is shown at higher magnification in $B . A-C$, Papillae were from 19-d-old rats. $D, E$, Papillae were from 27-d-old rats. Autoradiographic exposure on Kodak NTB3 emulsion was for $61 / 2$ weeks $(A-C)$ or 8 weeks $(D, E) . B, D$, Open arrows indicate taste buds with concentrations of silver grains, indicating mGluR4 mRNA. $C$, E, Filled arrows indicate the same taste buds as in $B$ and $D$, respectively, but which remain unlabeled after hybridization with the sense probe. Control hybridizations with a gustducin antisense $(F)$ probe in rat foliate papillae demonstrate that grain densities are substantially higher than those for mGluR4. The hybridization was performed in parallel on adjacent sections to those shown in $D$ and $E$. Autoradiographic exposure, 8 weeks. Scale bar, $50 \mu \mathrm{m}$.

tested whether rats generalized this aversion to any of the glutamate agonists. These data are shown in Figure 6. Altogether, 64 rats were tested as described in Materials and Methods. No taste aversions were detected in any of the control groups (rats injected with $\mathrm{NaCl})($ all $F<2.0)$. In contrast, all experimental groups (rats injected with $\mathrm{LiCl}$ ) showed a significant aversion to MSG when compared with their control group $(p<0.01)$. The aversion to MSG generalized in a dose-dependent manner to certain agonists but not to others (see Fig. 6). In particular, no significant differences in lick rates were found between control and experimental rats tested with either AMPA or NMDA (Fig. 6, open triangles) ( $F$
$<1.0)$. In contrast, when compared with control rats, experimental rats showed a dose-dependent suppression of lick rates when tested with L-AP4 (Fig. 6, open squares) $\left(F_{(2,28)}=5.36 ; p<0.025\right)$. Responses to 5 and $10 \mathrm{~mm}$ L-AP4 were suppressed. Post hoc comparison revealed significantly greater suppression at 10 than at $5 \mathrm{~mm}(p<0.01)$. For rats tested with KA, experimental rats licked at rates significantly less than those of the control rats $\left(F_{(1,14)}=5.37 ; p<0.05\right)$ but, in this case, only when presented with the highest concentration $(p<0.05)$.

The results indicated that rats generalized an MSG aversion to some, but not all, glutamate agonists. A one-way ANOVA was 

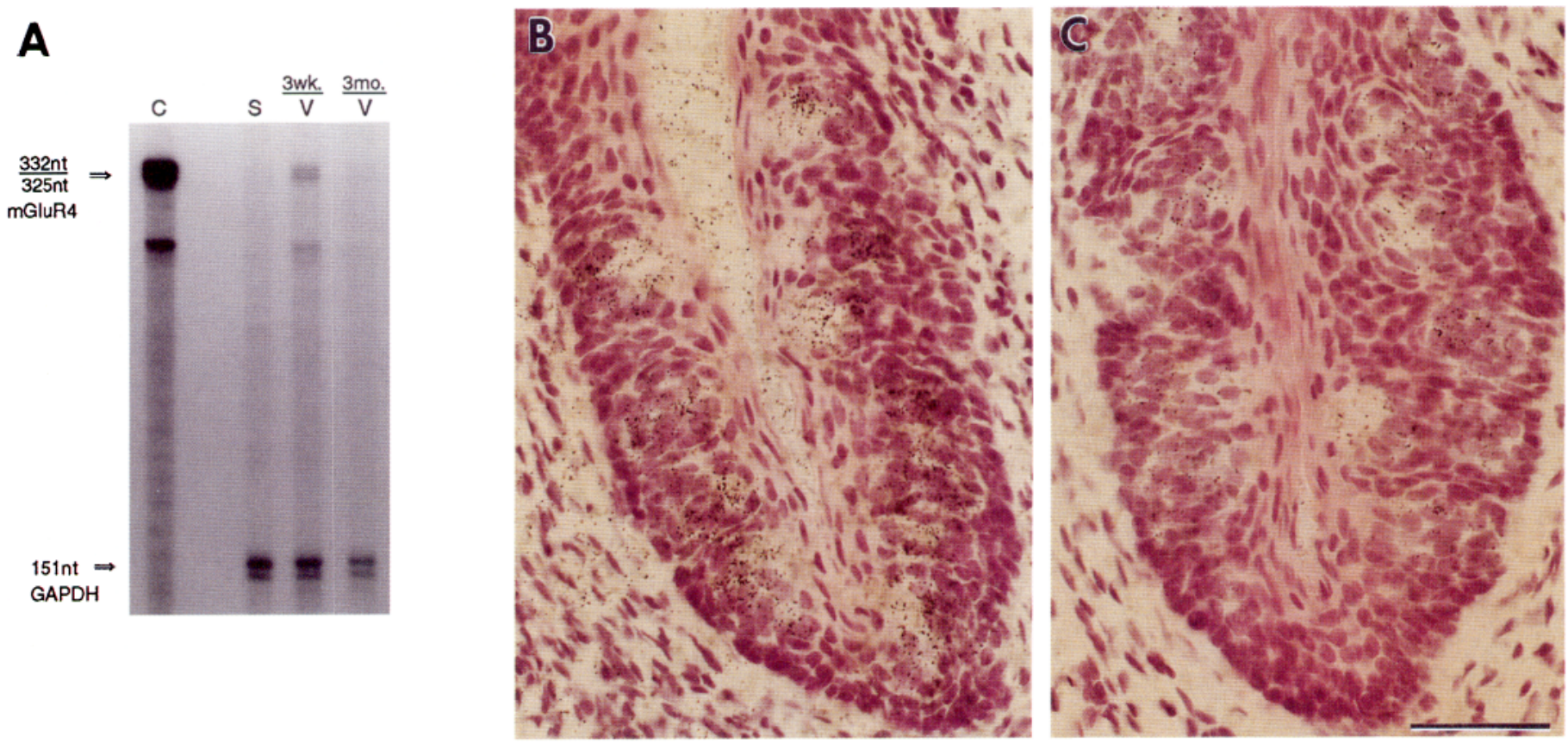

Figure 5. Expression of mGluR4 in taste buds during postnatal development. $A$, RNase protection assays were performed with $9 \mu \mathrm{g}$ poly(A)RNA from vallate plus foliate papillae $(V)$ from either 19- to 26-d-old preweaning rats $(3 w k$.) or 3-month-old adult rats $(3 \mathrm{mo}$.). The $x$-ray film was exposed for 17 d. The radioactivity in the mGluR4 doublet bands was densitometrically quantified and was normalized to the control GAPDH signal in the same lane. In three experiments using separate batches of mRNA, the protected doublet, $332 / 325 \mathrm{nt}$, indicated mGluR4 mRNA was found at an average of two- to threefold higher concentration in the younger animals. B, C, In situ hybridizations were run identically in parallel on vallate papillae from a 27 -d-old juvenile rat $(B)$ and a 120 -d-old adult rat $(C)$. Antisense probes for mGluR4, labeled with ${ }^{33} \mathrm{P}$, demonstrate the higher grain density (indicating higher mRNA levels) obtained in taste buds from juvenile rats. Autoradiographic exposure, 8 weeks. Scale bar, $50 \mu \mathrm{m}$.

used to compare data for the highest concentrations of MSG and each glutamate agonist shown in Figure 6. The data for these concentrations could be compared because these solutions had suppressed responses to similar extents in the first series of experiments. Furthermore, they were the concentrations that showed the greatest likelihood of generalization of MSG taste aversion in the second series of experiments. The analysis revealed significant group differences $\left(F_{(4,33)}=9.75 ; p<0.001\right)$. Post hoc comparisons revealed that, whereas LRs for $50 \mathrm{~mm}$ MSG and $10 \mathrm{~mm}$ L-AP4 did not differ significantly, the LRs for these two solutions were significantly less than those for the other glutamate agonists $(p<0.01)$. The results indicate that MSG taste aversion generalizes more to L-AP4 than to any of the other glutamate agonists.

\section{DISCUSSION}

Unlike vision or olfaction, the sense of taste is mediated peripherally via a diversity of transduction mechanisms (Ronnet and Payne, 1995). Taste cells are thought to express a number of receptors of distinct specificities. This may account for the variety of chemical substances that can elicit taste. Our results indicate that mGluR4 is associated uniquely with taste buds within the lingual epithelium of rats. mRNA for this G-protein-coupled receptor is not found in surrounding nontaste epithelium. Furthermore, mGluR4 expression is at higher levels in juvenile animals that have a higher taste sensitivity to glutamate relative to adults. More important, pharmacological activation of the mGluR4 receptor mimics the taste perception of MSG in a behavioral test. Based on these observations, we postulate that mGluR4 may be a chemosensory receptor in taste buds that is involved in transducing the taste of MSG. We cannot exclude the possibility that other GluRs, present both in taste buds and in surrounding nonsensory epithelia, may contribute to taste transduction. However, our behavioral data suggest that mGluR4 is the most likely candidate for the taste of MSG.

Several heptahelical (G-protein-coupled) receptors, similar to the putative odorant receptors, have been detected in lingual epithelium (Abe et al., 1993; Matsuoka et al., 1993). However, the mRNAs for those receptors were found at equal or higher concentration in surrounding nontaste epithelium rather than in taste buds. Thus, their role as taste receptors is debatable. Recently, receptor-like activity stimulated by a bitter taste substance (denatonium) has been demonstrated, but not purified, from bovine lingual membranes (Ruiz-Avila et al., 1995). Our results with mGluR4 are the first to demonstrate a receptor by molecular cloning that is expressed in taste buds and not in surrounding epithelium, making it a plausible candidate for a taste receptor. The recently cloned putative chemosensory receptors of Caenorhabditis elegans (Troemel et al., 1995) and putative mammalian pheromone receptors (Dulac and Axel, 1995) are also 7-transmembrane receptors coupled to G-proteins. Interestingly, the extracellular, ligand-binding regions of the $\mathrm{N}$ termini of mGluRs (O'Hara et al., 1993) and iGluRs (Stern-Bach et al., 1994) bear sequence and structural similarities to certain bacterial periplasmic-binding proteins. These prokaryotic proteins are believed to sequester nutritional components from the environment and may represent primitive chemosensory receptors.

Glutamate receptors in taste buds have been inferred from binding studies (Torii and Cagan, 1980; Cagan, 1987). These studies showed saturable binding of $\left[{ }^{3} \mathrm{H}\right]$ Lglutamate to membrane preparations from bovine vallate papillae. The affinity of taste 


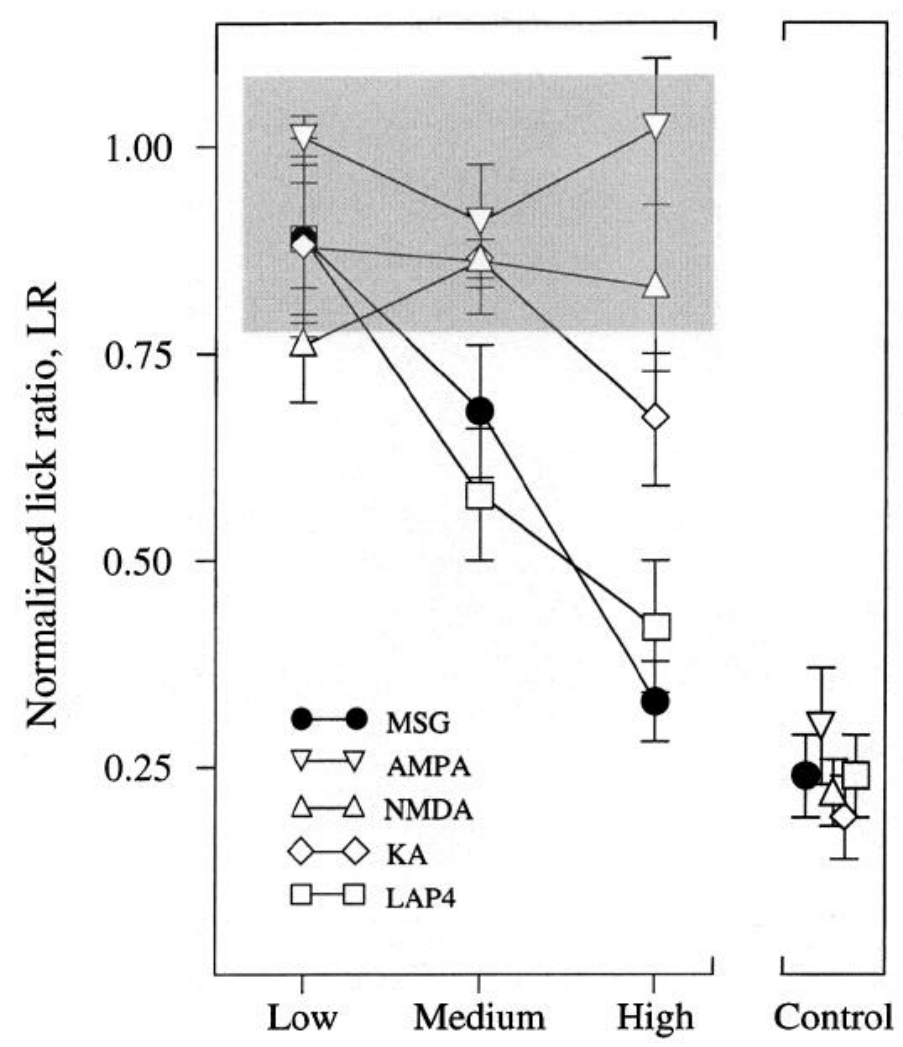

\section{Concentration of taste stimuli}

Figure 6. Conditioned taste aversion indicates that L-AP4, an agonist for mGluR4, mimics the taste of MSG in rats. Rats were conditioned to avoid solutions containing MSG and then were presented with three concentrations of MSG, AMPA, KA, NMDA, or L-AP4, as described in Materials and Methods. Ordinate, Lick rate in experimental rats normalized to rate in control rats. Abscissa, Concentration of test substances, as specified in Materials and Methods. Each point is the mean \pm SEM $(n=6-8$ conditioned and $6-8$ control rats per data point). The shaded area represents the range of responses to $25 \mathrm{~mm} \mathrm{KCl}$, a neutral distractor, to indicate nonspecific aversive behavior (see Materials and Methods). Control, For each animal a single, maximal concentration of MSG (150 mM) was tested also to verify that complete aversion to MSG had been established. The mean \pm SEM of normalized $L R$ for each group is shown.

receptors for glutamate is very low $\left(K_{\mathrm{D}}=20-30 \mathrm{~mm}\right.$ ) (Torii and Cagan, 1980) relative to most synaptic glutamate receptors $\left(\mathrm{EC}_{50}\right.$ $=1-20 \mu \mathrm{M})($ Hollmann and Heinemann, 1994). Nonetheless, the binding affinity of glutamate at taste receptors is in the same range as taste thresholds for glutamate (1-10 mM in rats) (Yamamoto et al., 1991). This implies that GluRs in taste buds may possess ligand-binding sites different from those of synaptic receptors. The glutamate-binding site of synaptic GluRs is predicted to be in the large extracellular N terminus (O'Hara et al., 1993). It should be noted that the PCR product reported in this paper is downstream of the postulated glutamate-binding region. It is possible that in taste cells alternative splicing or other post-transcriptional modifications could give rise to an extracellular $\mathrm{N}$ terminus with a structure distinct from brain mGluR4. This could serve as the structural basis for the different binding affinities noted above. We are in the process of obtaining and analyzing full-length cDNA clones to examine this question.

The binding of glutamate to taste receptors as well as the perceived taste of MSG is potentiated by $5^{\prime}$-IMP and $5^{\prime}$-GMP
(Sato and Akaike, 1965; Torii and Cagan, 1980; Yamamoto et al., 1991). The primary sequence of the extracellular $\mathrm{N}$ terminus of brain mGluR4 does not contain consensus nucleotide-binding motifs. However, certain brain iGluRs, including KA-selective receptors, do possess such sites and/or are known to be modulated functionally by nucleotides (Henley, 1994). Further studies may reveal sites for nucleotide interaction within the sequences of taste glutamate receptors. Also, interactions between mGluR4 and other receptors may be important for the complete taste perception of glutamate, termed umami. mGluRs and iGluRs are known to be coexpressed and functionally coupled in certain neurons (Harvey and Collingridge, 1993; Schoepp and Conn, 1993; Fitzjohn et al., 1995; Shen et al., 1995).

CTA has been used to study perceptual similarities among taste substances (Spector and Grill, 1988). Generalization in CTA experiments is sensitive to both the quality (sweet, sour, etc.) and the perceived intensity (concentration) of the conditioned and test stimuli. The similarity between the taste qualities of MSG and L-AP4 (an agonist at the mGluR4 receptor) is demonstrated in Figure 6. The generalization between MSG and L-AP4 is dosedependent over a range of concentrations. We interpret these results to imply that the taste receptor for MSG is activated also by L-AP4, thus producing similar taste qualities for these two substances. It is possible that, in our experiments, the other agonists, although readily detectable to rats, produced tastes less intense than the tastes produced by MSG and L-AP4. Thus, we cannot rule out that higher concentrations of AMPA, KA, or NMDA might yield some taste generalization.

In transfected Chinese hamster ovary cells, activation of mGluR4 is associated with decreases in cAMP via inhibition of a cyclase (Tanabe et al., 1993). Whether mGluR4 signaling in specific neurons and in taste cells is linked via inhibition of a nucleotide cyclase or via activation of a phosphodiesterase would depend on the presence of appropriate G-proteins and the regulatable enzymes required for these alternative pathways. MSG has been claimed to modulate other basic tastes (Sjöström, 1980; Maga, 1983; Pritchard and Norgren, 1991). If mGluR4 is a taste receptor, its activation by dietary glutamate would presumably trigger a second messenger cascade that could regulate the transduction of other taste stimuli. Although several G-proteins, including gustducin and transducin, are localized in taste buds (McLaughlin et al., 1993; Finger et al., 1995; Ruiz-Avila et al., 1995), a functional linkage with mGluRs remains to be elucidated.

Electrophysiological studies using membrane fractions from mouse tongue (not specifically from taste buds) incorporated into bilayers demonstrated the presence of receptors activated by glutamate and NMDA (Brand et al., 1991). mGluRs would not be detected in such experiments. Our results are compatible with these studies, because we also found evidence for several iGluRs, including NMDAR1, in lingual tissues. Also, there have been reports of widespread expression of mRNA for NMDAR1 in peripheral nervous tissues (Shigemoto et al., 1992; Burns et al., 1994; Watanabe et al., 1994). More recently, ionic conductances and changes in cytosolic $\mathrm{Ca}^{2+}$ in response to applied glutamate have been recorded from mouse and rat taste buds (Sugimoto, 1994; Bigiani et al., 1995; Hayashi et al., 1995).

\section{REFERENCES}

Abe T, Sugihara H, Nawa H, Shigemoto R, Mizuno N, Nakanishi S (1992) Molecular characterization of a novel metabotropic glutamate receptor mGluR5 coupled to inositol phosphate/ $\mathrm{Ca}^{2+}$ signal transduction. J Biol Chem 267:13361-13368. 
Abe K, Kusakabe Y, Tanemura K, Emori Y, Arai S (1993) Primary structure and cell-type specific expression of a gustatory $G$ proteincoupled receptor related to olfactory receptors. J Biol Chem 268:12033-12039.

Akabas MH (1993) The molecular biology of chemotransduction. In: Mechanisms of taste transduction (Simon SA, Roper SD, eds), pp 175-200. Boca Raton, FL: CRC.

Akabas MH, Dodd J, Al-Awqati Q (1988) A bitter substance induces a rise in intracellular calcium in a sub-population of rat taste cells. Science 242:1047-1050

Avenet P, Hofmann F, Lindemann B (1988) Transduction in taste receptor cells requires cAMP-dependent protein kinase. Nature 331:51-54.

Avenet P, Kinnamon SC, Roper SD (1993) Peripheral transduction mechanisms. In: Mechanisms of taste transduction (Simon SA, Roper SD, eds), pp 161-174. Boca Raton, FL: CRC.

Bigiani A, Delay RJ, Chaudhari N, Kinnamon SC, Roper SD (1995) Responses to glutamate in isolated rat taste cells. Soc Neurosci Abstr 21:1656.

Brand JG, Teeter JH, Kumazawa T, Huque T, Bayley DL (1991) Transduction mechanisms for the taste of amino acids. Physiol Behav 49:899-904.

Burns GA, Stephens KE, Benson JA (1994) Expression of mRNA for the $N$-methyl-D-aspartate (NMDAR1) receptor by the enteric neurons of the rat. Neurosci Lett 170:87-90.

Cagan RH (1987) Allosteric regulation of glutamate taste receptor function. In: Umami: a basic taste (Kawamura Y, Kare MR, eds), pp 155-172. New York: Dekker.

Cartford C, Than T, Delay E, Roper S (1994) Using conditioned taste aversion to characterize glutamate receptors underlying MSG taste. Chem Senses 19:451-452.

Chaudhari N, Lamp C, Yang H, Porter A, Minyard M, Roper S (1994) The molecular biology of glutamate receptors in rat taste buds. In: Olfaction and taste, Vol XI (Kurihara K, Suzuki N, Ogawa H, eds), pp 382-383. Tokyo: Springer.

Ciabarra AM, Sullivan JM, Gahn LG, Pecht G, Heinemann S, Sevarino KA (1995) Cloning and characterization of $\chi$-1: a developmentally regulated member of a novel class of the ionotropic glutamate receptor family. J Neurosci 15:6498-6508.

Cummings TA, Powell J, Kinnamon SC (1993) Sweet taste transduction in hamster taste cells: evidence for the role of cyclic nucleotides. J Neurophysiol 70:2326-2336.

Dulac C, Axel R (1995) A novel family of genes encoding putative pheromone receptors in mammals. Cell 83:195-206.

Durand GM, Gregor P, Zheng X, Bennett MVL, Uhl GR, Zukin RS (1992) Cloning of an apparent splice variant of the rat $N$-methyl-Daspartate receptor NMDAR1 with altered sensitivity to polyamines and activators of protein kinase C. Proc Natl Acad Sci USA 89:9359-9363.

Faurion A (1991) Are umami taste receptor sites structurally related to glutamate CNS receptor sites? Physiol Behav 49:905-912.

Finger TE, Bottger B, Kim D-J, Roper S (1995) Different populations of taste cells exhibit gustducin and serotonin immunoreactivities. Chem Senses 20:667-668.

Fitzjohn SM, Berretta N, Irving AJ, Harvey J, Lodge D, Collingridge GL (1995) Potentiation of responses to NMDA by metabotropic glutamate receptors in the rat hippocampus. Soc Neurosci Abstr 21:77.

Gilbertson DM, Gilbertson TA (1994) Amiloride reduces the aversiveness of acids in preference tests. Physiol Behav 56:649-654.

Gilbertson TA (1993) The physiology of vertebrate taste reception. Curr Opin Neurobiol 3:532-539.

Harvey J, Collingridge GL (1993) Signal transduction pathways involved in the acute potentiation of NMDA responses by 1S,3R-ACPD in rat hippocampal slices. Br J Pharmacol 109:1085-1090.

Hayashi Y, Restrepo D, Teeter J (1995) Responses to monosodium glutamate in mouse taste cells. Chem Senses 20:706

Heck GL, Mierson S, DeSimone J (1984) Salt taste transduction occurs through an amiloride-sensitive transport pathway. Science 223:403-405.

Henley JM (1994) Kainate binding proteins: phylogeny, structures and possible functions. Trends Pharmacol Sci 15:182-190.

Hod Y (1992) A simplified ribonuclease protection assay. Biotechniques 13:852-853.

Hollmann M, Heinemann S (1994) Cloned glutamate receptors. Annu Rev Neurosci 17:31-108.

Houamed KM, Kuijper JL, Gilbert TL, Haldeman BA, O'Hara PJ, Mulvihill ER, Almers W, Hagen FS (1991) Cloning, expression, and gene structure of a G-protein-coupled glutamate receptor from rat brain. Science 252:1318-1321.

Hwang PM, Verma A, Bredt DS, Snyder SH (1990) Localization of phosphatidylinositol signaling components in rat taste cells: role in bitter taste transduction. Proc Natl Acad Sci USA 87:7395-7399.

Kawamura Y, Kare MR, eds (1987) Introduction to: Umami, a basic taste. New York: Dekker.

Kinnamon SC (1988) Taste transduction: a diversity of mechanisms. Trends Neurosci 11:491-496.

Kintner CR, Melton DA (1987) Expression of Xenopus N-CAM RNA is an early response of ectoderm to induction. Development 99:311-325.

Lancet D, Ben-Arie N (1993) Olfactory receptors. Curr Biol 3:668-674

Libert F, Parmentier M, Lefort A, Dinsart C, Van Sande J, Maenhaut C Simons M-J, Dumont JE, Vassart G (1989) Selective amplification and cloning of four new members of the G-protein-coupled receptor family. Science 244:569-572.

Lindemann B (1995) Sweet and salty: transduction in taste. News Physiol Sci 10:166-170.

Maga JA (1983) Flavor potentiators. CRC Crit Rev Food Sci Nutr $18: 231-312$

Margalit T, Lancet D (1993) Expression of olfactory receptor and transduction genes during rat development. Dev Brain Res 73:7-16.

Masu M, Tanabe Y, Tsuchida K, Shigemoto R, Nakanishi S (1991) Sequence and expression of a metabotropic glutamate receptor. Nature 349:760-765

Matsuoka I, Mori T, Aoki J, Sato T, Kurihara K (1993) Identification of novel members of G-protein-coupled receptor superfamily expressed in bovine taste tissue. Biochem Biophys Res Commun 194:504-511.

McLaughlin SK, Margolskee RF (1993) ${ }^{1.3} \mathrm{P}$ is preferable to ${ }^{3.3} \mathrm{~S}$ for labeling probes used in in situ hybridization. Biotechniques 15:506-511.

McLaughlin SK, McKinnon PJ, Margolskee RF (1992) Gustducin is a taste-cell-specific G protein closely related to the transducins. Nature 357:563-569.

McLaughlin SK, McKinnon PJ, Robichon A, Spickofsky N, Margolskee RF (1993) Gustducin and transducin: a tale of two G proteins. Ciba Found Symp 179:186-196.

Moriyoshi K, Masu M, Ishii T, Shigemoto R, Mizuno N, Nakanishi S (1991) Molecular cloning and characterization of the rat NMDA receptor. Nature 354:31-37.

Nakajima Y, Iwakabe H, Akazawa C, Nawa H, Shegemoto R, Mizuno N, Nakanishi S (1993) Molecular characterization of a novel retinal metabotropic glutamate receptor mGluR6 with a high agonist selectivity for L-2-amino-4-phosphonobutyrate. J Biol Chem 268:11868-11873.

Nakanishi N, Axel R, Shneider NA (1992) Alternative splicing generates functionally distinct $N$-methyl-D-aspartate receptors. Proc Natl $\wedge$ cad $\mathrm{Sci}$ USA 89:8552-8556.

Ninomiya Y, Tanikukai T, Yoshida S, Funakoshi M (1991) Gustatory neural respunses in preweanling mice. Physiol Behav 49:913-918.

Nowlis GH, Frank ME, Pfaffmann C (1980) Specificity of acquired aversions to taste qualities in hamsters and rats. J Comp Physiol [A] 94:932-942.

O'Hara PJ, Sheppard PO, Thogersen H, Venezia D. Haldeman BA, McGrane V, Houamed KM, Thomsen C, Gilbert TL. Mulvihill ER (1993) The ligand-binding domain in metabotropic glutamate receptors is related to bacterial periplasmic binding proteins. Neuron 11:1-20.

Pritchard TC, Norgren R (1991) Preference of Old World monkcys for amino acids and other gustatory stimuli: the influence of monosodium glutamate. Physiol Behav 49:1003-1007.

Reed RR (1992) Signaling pathways in odorant detection. Neuron 8:205-209.

Ronnett GV, Payne R (1995) A tale of two senses. Neuron 15:11-16.

Roper SD (1992) The microphysiology of peripheral taste organs. J Neurosci 12:1127-1134.

Ruiz-Avila L, McLaughlin SK, Wildman D, McKinnon PJ, Robichon A, Spickofsky N, Margolskee RF (1995) Coupling of bitter receptor to phosphodiesterase through transducin in taste receptor cells. Nature 376:80-85.

Saiki RK, Gelfand DH, Stoffel S, Scharf SJ, Higuchi R, Horn GT, Mullis $\mathrm{K}$, Erlich HA (1988) Primer-directed enzymatic amplification of DNA with a thermostable DNA polymerase. Science 239:487-491.

Sato M, Akaike N (1965) 5' ribonucleotides as gustatory stimuli in rats: electrophysiological studies. Jpn J Physiol 15:53-70.

Saugstad JA, Kinzie JM, Mulvihill, ER, Segerson TP, Westbrook GL (1994) Cloning and expression of a new member of the L-2-amino-4- 
phosphonobutyric acid-scnsitive class of metabotropic glutamate receptors. Mol Pharmacol 45:367-372.

Schoepp DD, Conn PJ (1993) Metabotropic glutamate receptors in brain function and pathology. Trends Pharmacol Sci 14:13-20.

Shen H, Gorter JA, Aronica E, Zheng X, Zhang L, Bennett MVL, Zukin RS (1995) Potentiation of NMDA responses by metabotropic receptor activation depends on NMDA receptor subunit composition. Soc Neurosci Abstr 21:77.

Shigemoto R, Ohishi H, Nakanishi S, Mizuno N (1992) Expression of the mRNA for the rat NMDA receptor (NMDAR1) in the sensory and autonomic ganglion neurons. Neurosci Lett 144:229-232.

Sjöström LB (1972) Flavor potentiators. In: CRC handbook of food additives (Furia TE, ed), pp 513-521. Boca Raton, FL: CRC.

Smith JC (1970) Conditioned suppression as an animal psychophysical technique. In: Animal psychophysics: the design and conduct of sensory experiments (Stebbins WC, ed), pp 125-159. New York: Appleton-Century-Crofts.

Spector AC, Grill HG (1988) Differences in the taste quality of maltose and sucrose in rats: issues involving the generalization of conditioned taste aversions. Chem Senses 13:95-113.

Stern-Bach Y, Bettler B, Hartley M, Sheppard PO, O'Hara PJ, Heinemann SF (1994) Agonist selectivity of glutamate receptors is specified by two domains structurally related to bacterial amino acid-binding proteins. Neuron 13:1345-1357.

Striem BJ, Pace U, Zehavi U, Naim M, Lancet D (1989) Sweet tastants stimulate adenylate cyclase coupled to GTP-binding protein in rat membranes. Biochem J 260:121-126.

Striem BJ, Naim M, Lindemann B (1991) Generation of cyclic AMP in taste buds of the rat circunvallate papilla in response to sucrose. Ccll Physiol Biochem 1:46-54.
Sugimoto K (1994) Electrophysiological properties and chemicallyinduced responses of mammalian taste bud cells. In: Olfaction and taste, Vol XI (Kurihara K, Suzuki N, Ogawa H, eds), p 111. Tokyo: Springer.

Tanabe Y, Masu M, Ishii T, Shigemoto R, Nakanishi S (1992) A family of metabotropic glutamate receptors. Neuron 8:169-179.

Tanabe Y, Nomura A, Masu M, Shigemoto R, Mizuno N, Nakanishi S (1993) Signal transduction, pharmacological properties and expression patterns of two rat metabotropic glutamate receptors, mGluR3 and mGluR4. J Neurosci 13:1372-1378.

Tapper DN, Halpern BP (1968) Taste stimuli: a behavioural categorization. Science 161:708-710.

Torii K, Cagan RH (1980) Biochemical studies of taste sensation. IX. Enhancement of $\mathrm{L}-\left[{ }^{3} \mathrm{H}\right]$ glutamate binding to bovine taste papillae by $5^{\prime}$ ribonucleotides. Biochim Biophys Acta 627:313 323.

Troemel ER, Chou JH, Dwyer ND, Colbert HA, Bargmann CI (1995) Divergent seven transmembrane receptors are candidate chemosensory receptors in C. elegans. Cell 83:207-218.

Watanabe M, Mishina M, Inoue Y (1994) Distinct gene expression of the $N$-methyl-D-aspartate receptor channel subunit in peripheral neurons of the mouse sensory ganglia and adrenal gland. Neurosci Lett 165:183-186.

Wisden W, Morris BJ, Hunt SP (1991) In situ hybridization with synthetic DNA probes. In: Molecular neurobiology (Chad J, Wheal H, eds), pp 205-225. Oxford: IRL.

Yamamoto T, Matsuo R, Fujimoto Y, Fukunaga I, Miyasaka A, Imoto T (1991) Electrophysiological and behavioral studies on the taste of umami substances in the rat. Physiol Behav 49:919-925.

Yarfitz S, Hurlcy JB (1994) Transduction mechanisms of vertebrate and invertebrate photoreceptors. J Biol Chem 269;14329-14332. 